JOANNA SOSNOWSKA

Uniwersytet Łódzki

\title{
Wychowanie do samodzielności - rola nauczyciela wychowania przedszkolnego w kreowaniu otoczenia wokół dziecka
}

\author{
Pozwólcie dziecku doświadczać po omacku, wydtużać swe korzenie, \\ eksperymentować i drążý, dowiadywać się i porównywać, \\ szukać w ksiqżkach i materiałach źródtowych, \\ zanurzać swq ciekawość w kapryśnych gtębinach wiedzy, \\ pozwólcie mu wyruszać w podróże odkrywcze, \\ czasem trudne - ale pozwalajace znaleźć taki pokarm, \\ jaki będzie dla niego pożywny. \\ (C. Freinet, Gawędy Mateusza) ${ }^{1}$
}

Człowiek samodzielny, to - zgodnie z określeniami zawartymi w słowniku - wolny, niezależny, niezawisty, zaradny, aktywny². Samodzielność dziecka, w wyniku badań Kingi Kuszak, wynika z potrzeby niezależnego zdobywania i gromadzenia doświadczeń, pokonywania przeszkód oraz weryfikowania własnych umiejętności w różnych sytuacjach życiowych ${ }^{3}$. Jest związana - jak sądzi autorka $-z$ gotowościa do podjęcia kolejnych prób działania $w$ celu realizacji zamierzenia, a także $z$ umiejętnościa poniesienia konsekwencji własnych wyborów $i$ decyzji ${ }^{4}$. Rodzice dzieci w wieku przedszkolnym, pod pojęciem samodzielności, w odniesieniu do własnego dziecka, rozumieją, m.in. 1) umiejętność wykonywania codziennych podstawowych obowiazków $w$ domu bez pomocy dorostych; 2) zdolność podejmowania niektórych decyzji; 3) umiejętność rozwiqzywania problemów; 4) podejmowanie i wykonywanie, z własnej

\footnotetext{
${ }^{1}$ Cytat podaję za: B. Kalmanowicz, B. Lauba, B. Papierz, A. Sowińska, Program wychowawczy dla dzieci od 3 do 10 roku życia na podstawie serii ksiażek „,Kamyczek”, Warszawa 2005, s. 11. s. 216.

${ }^{2}$ A. Latusek (red.), Praktyczny stownik wyrazów i zwrotów bliskoznacznych, Kraków 2004,

${ }^{3}$ K. Kuszak, Dynamika rozwoju samodzielności dziecka $w$ wieku przedszkolnym, Poznań 2006, s. 7.

${ }^{4}$ Tamże.
} 
inicjatywy, różnych czynności w zależności od potrzeb, bądź 4) wykonywanie czynności bez pomocy, przy zachowaniu gradacji stopnia trudności, $w$ zależności od wieku ${ }^{5}$. Dzieciom 5- i 6-letnim, samodzielność kojarzy się z sytuacją, kiedy: Ktoś chce coś zrobić sam, Ktoś coś robi bez niczyjej pomocy, Jakaś osoba sobie poradzi, Nie potrzebuje sie pomocy ${ }^{6}$. Dla dorosłych, jak i dla dzieci pojęcie to oznacza sytuację działania mającego niewątpliwie cechę indywidualności. Jest to proces trwający przez całe życie, ale najbardziej intensywne w nim zmiany zachodzą w dzieciństwie i w wieku dojrzewania.

$\mathrm{W}$ świetle podstawy programowej wychowania przedszkolnego z $2008 \mathrm{r}$,, jednym z celów wychowania jest - poprzez wspieranie ciekawości, aktywności i samodzielności - zapewnienie dzieciom lepszych szans edukacyjnych ${ }^{7}$. Cel ten realizowany jest w obszarze drugim podstawy programowej: Ksztattowanie czynności samoobstugowych, nawyków higienicznych i kulturalnych. Wdrażanie dzieci do utrzymywania tadu i porzadku ${ }^{8}$. Sformułowane w tym obszarze oczekiwania wobec dziecka mieszczą się także w zakresie edukacji społecznej i w realizacji winny być przesycone treściami wychowawczymi.

Osiągnięcia wychowanków w pierwszym etapie edukacyjnym, w zakresie samodzielności, ale i związanej z nią sfery motywacji, emocji, poczucia własnej wartości czy relacji interpersonalnych, wpływają na funkcjonowanie w nowej, szkolnej i pozaszkolnej rzeczywistości. Samodzielne dziecko, to w przyszłości samodzielny dorosły, radzący sobie z wymaganiami stawianymi przez życie człowiek, który kiedyś w pełni wykorzysta swój potencjał rozwojowy. Właśnie na dorosłych - nauczycielach w przedszkolu, w szkole, ale również rodzicach, w środowisku domowym, spoczywa odpowiedzialność związana $\mathrm{z}$ nauką stawania się samodzielnym, z wychowaniem dziecka do samodzielności. Nie ma

${ }^{5}$ Odpowiedzi uzyskano na podstawie badań ankietowych przeprowadzonych wśród rodziców dzieci w jednej z placówek przedszkolnych w Łodzi. Wśród innych wypowiedzi rodziców na temat samodzielności jako pojęcia, pojawiły się konkretne zachowania dziecka, np.: 1) ...gdy dziecko samo przygotuje sobie kanapki, zawiaże buty, ubierze się; 2) ...umie przy sobie zrobic podstawowe rzeczy (zje, myje się, ubiera, sprzata po sobie), sam decyduje w co się ubierze, co zje, $w$ co chce się bawić; 3) ...umiejętność samodzielnego uczenia się, bez obecności rodzica, przy biurku, samodzielnej zabawy; uprawianie sportów z innymi dziećmi, a nie z rodzicami.

${ }^{6}$ Próbę określenia pojęcia „samodzielność” podjęły dzieci w jednym z przedszkoli w Łodzi.

${ }^{7}$ Rozporzqdzenie Ministra Edukacji Narodowej z dnia 23 grudnia 2008 r. w sprawie podstawy programowej wychowania przedszkolnego dla przedszkoli, oddziałów przedszkolnych w szkołach podstawowych oraz innych form wychowania przedszkolnego, Dz. U. 2009, $\mathrm{nr} 4$, poz. 17,

${ }^{8}$ Oczekiwania wobec dziecka w tym obszarze brzmią następująco: Dziecko kończqce przedszkole i rozpoczynajace naukę $w$ szkole podstawowej: 1) umie poprawnie umyć się i wytrzeć oraz umyć zęby; 2) wtaściwie zachowuje się przy stole podczas positków, nakrywa do stotu i sprzata po sobie; 3) samodzielnie korzysta z toalety; 4) samodzielnie ubiera sie i rozbiera, dba o osobiste rzeczy $i$ nie naraża ich na zgubienie lub kradzież; 5) utrzymuje porzadek $w$ swoim otoczeniu. Tamże. 
gotowych wzorców na formowanie samodzielności małego dziecka, determinuje ją wiele czynników, jak chociażby świadomość, że każde dziecko ma własne tempo rozwoju i stopień usamodzielnienia zależy od jego aktualnych możliwości, potrzeb, uzdolnień, ale i otoczenia, w którym przebywa. W przedszkolu i szkole jest wiele sytuacji okazjonalnych lub intencjonalnych, które nauczyciel może wykorzystać, by uczyć i doskonalić samodzielne działania wychowanków. Wdrażanie do samodzielności to trudna sztuka. Należy zachować umiar i właściwe proporcje. Jak radzi nauczycielka szkoły podstawowej, Joanna Gładysz: Nasza pomoc musi być przede wszystkim taktowna i dyskretna. Cenne jest zwtaszcza naprowadzanie dziecka, zmuszajqce do samodzielnego myślenia9 .

Artykuł ten odwołuje się do praktyki wypływającej ze środowiska przedszkolnego, przybliża sposób pracy nauczyciela z dzieckiem, w którym wychowawca, świadomie i mądrze, wspiera wychowanka w osiąganiu samodzielności. Nauczyciel jest tu towarzyszem, który pomaga dziecku uzyskać przede wszystkim niezależność intelektualną.

Na początek warto zapoznać się z teoriami opisującymi problem samodzielności, bowiem w zależności od kierunku myślenia o człowieku, ukształtowały się zupełnie odmienne jego interpretacje. W świetle analizy K. Kuszak, koncepcje teoretyczne określają samodzielność jednostki jako:

- nawyk,

- poczucie podmiotowości,

- nabywanie przez człowieka doświadczeń życiowych,

- postawę $e^{10}$.

Punktem odniesienia dla behawioryzmu jest samodzielność jako sprawność pozwalająca na wykonanie czynności bez pomocy innych osób, umiejętność osiagana dzięki systematycznie powtarzanym ćwiczeniom, czego konsekwencją staje się nawyk. Precyzja i koordynacja ruchów obecna podczas wykonywania danej czynności stopniowo uniezależnia jednostkę od pomocy z zewnątrz ${ }^{11}$. Dodatkowym czynnikiem wpływającym na zdobycie przez nią samodzielności są w tym przypadku wzmocnienia pozytywne dawane przez otoczenie. O samodzielności jako nawyku można mówić, zwłaszcza w wyniku relacji jednostki ze środowiskiem społecznym. Na powtarzanie zachowań bądź czynności akceptowanych przez ogół ma wpływ nagroda w formie pochwały czy aprobaty.

W koncepcjach humanistycznych człowiek samodzielny sam decyduje o własnej aktywności, sam też ustala i realizuje kolejność wyznaczonych

${ }^{9}$ Gładysz J., Dziecko samo dzielne!, ,Bliżej Przedszkola” 2009, nr 9, s. $26-27$.

${ }^{10}$ K. Kuszak, Dynamika rozwoju samodzielności..., s. 11-17.

${ }^{11}$ Autorka przytacza koncepcję M. Biegajło, zgodnie z którą wielokrotnie oraz intensywnie podejmowane próby działań zwiększają prawdopodobieństwo opanowania określonych umiejętności przez jednostkę i jednocześnie wyrabiają elastyczność oraz otwartość na sytuacje trudne. Tamże, s. 12. 
działań, przez co staje się ich podmiotem. Podmiotowość zakłada - z jednej strony - świadomość odrębności w stosunku do innych ludzi, jak i otaczającego świata, ale $\mathrm{z}$ drugiej oczekuje umiejętności kierowania własnym postępowaniem, przestrzegania norm prawno-moralnych oraz odpowiedzialności za podejmowane decyzje. Człowiek samodzielny, będący jednocześnie podmiotem własnych działań, wobec osobistych sytuacji życiowych przyjmuje postawę odpowiedzialności za powierzone zadania. Samodzielność w takim aspekcie utożsamiana jest $\mathrm{z}$ samokontrolą, wewnętrzną dyscypliną, wytrwałością. Autorzy koncepcji humanistycznych ${ }^{12}$ podkreślają nie tyle sam fakt bycia, ale proces stopniowego „stawania się" człowiekiem samodzielnym, dążenia do samodzielności. Rozwija się ona w miarę wzrostu poczucia własnej wartości jednostki oraz jej przekonania o możliwości samodzielnego pokonywania barier i problemów.

Teorie poznawcze określają samodzielność człowieka jako nabywanie doświadczeń życiowych, w związku z jego wrodzoną aktywnością, siłą, poszukiwaniem przeżyć, doznań, uczuć. Proces zbierania $i$ utrwalania doświadczeń jak utrzymuje K. Kuszak - polega na zapamiętywaniu treści i sposobów dochodzenia do celu bezpośrednio $w$ wyniku wtasnych dziatań lub pośrednio przez przyswajanie informacji pochodzqcych od innych ludzi, w wyniku wymiany aktywności między jednostkq a środowiskiem ${ }^{13}$. Autorka przytacza ciekawą koncepcję Włodzimierza Szewczuka, w której samodzielność nie jest dana człowiekowi od momentu narodzin, ale jest procesem stopniowego osiagania kontroli nad czynnikami determinującymi działanie dzięki ukształtowaniu się umiejętności ich wzajemnego przeciwstawiania, równoważenia oraz zastępowania, a także kompensacji jednych czynników innymi ${ }^{14}$. Stopniowe osiaganie samodzielności prowadzi do dojrzałości, a więc zdolności zaspokajania własnych potrzeb w relacji z otoczeniem, ale w sposób od niego niezależny.

Postawa, to inaczej stosunek człowieka do życia lub do pewnej wyróżnionej sfery zjawisk, wyrażający jego stanowisko, poglądy ${ }^{15}$. Koncepcja interpretacji samodzielności jako postawy wiąże się z działaniem jednostki i jest rezultatem jej samorealizacji. Człowiek, którego cechuje postawa samodzielności potrafi spojrzeć na siebie przez pryzmat określonego ideału własnego ja, co z kolei umożliwia mu dokonywanie autoewaluacji zachowań, w tym własnej samodzielności ${ }^{16}$. Zdaniem K. Kuszak, ujęcie samodzielności jako postawy, jest najbardziej pełne. W tym wymiarze, samodzielność obejmuje kilka komponentów:

${ }^{12}$ J. Reykowski akcentuje zwrot ,zmierzania ku samodzielności”. Por. K. Kuszak, Dynamika rozwoju samodzielności..., s. 14.

${ }^{13}$ Tamże, s. 15.

${ }^{14}$ Tamże, s. 16.

${ }^{15}$ M. Szymczak (red.), Stownik języka polskiego, Warszawa 1979, s. 842.

${ }^{16}$ K. Kuszak, Dynamika rozwoju samodzielności..., s. 17. 
- poznawczy - obserwacja własnych samodzielnych zachowań i porównywanie ich z ja idealnym,

- oceniający - stwierdzenie niedostatków w obrazie własnej samodzielności, co jest źródłem napięć emocjonalnych z jednej strony, ale z drugiej - świadomość, że człowiek zbliża się do własnego ideału, wywołuje pozytywne uczucia,

- emocjonalny - pojawienie się motywacji do pracy nad sobą w celu osiągnięcia pożądanego obrazu własnego $j a$,

- behawioralny - podejmowanie konkretnych działań zmierzających do uzyskania pewnego poziomu samodzielności, na bazie własnej wiedzy i doświadcze$\operatorname{nia}^{17}$.

W wielu, jak widać, koncepcjach teoretycznych interpretacja i podejście do problematyki samodzielności jednostki przebiega w sposób zróżnicowany. Podobnie przedstawia się kwestia określenia i nazwania obszarów, w których człowiek nabywa i doskonali własną samodzielność. W literaturze przedmiotu spotyka się różne ich ujęcia. Dla przykładu, Maria Tyszkowa wyodrębnia cztery sfery samodzielności: motoryczną, praktyczną, umysłową i w posługiwaniu się sygnałami, natomiast Wincenty Okoń, wskazuje ponadto na znaczenie samodzielności myślenia ${ }^{18}$.

W warunkach środowiska przedszkolnego można wskazać - zgodnie z sugestią K. Kuszak - następujące obszary samodzielności dziecka (autorka odnosi je do poziomu rozwoju dziecka czteroletniego):

- sfera działań związanych z samoobsługa,

- sfera czynności związana z realizacją zadań,

- sfera kontaktów społecznych,

- sfera emocji ${ }^{19}$.

W obszarze czynności samoobsługowych, pozwalających dziecku na pewną niezależność od dorosłych i świadczących o usamodzielnieniu, autorka sytuuje takie umiejętności jak: samodzielne jedzenie, ubieranie i rozbieranie się, wykonywanie czynności związanych z higieną osobistą, aranżowanie przestrzeni wokół siebie.

Samodzielna realizacja wytyczonego zadania wymaga od dziecka, m.in.: podjęcia decyzji, zorganizowania pracy i doboru odpowiednich narzędzi, poszukiwania odpowiednich rozwiązań. Rozwiązanie zadań zakłada przy tym: prośbę dziecka skierowaną do osoby dorosłej, poszukiwanie skutecznego sposobu działania oraz ocenę własnej działalności i wskazanie popełnionych błędów ${ }^{20}$.

${ }^{17}$ Tamże, s. 19.

${ }^{18}$ M. Tyszkowa, Aktywność $i$ dziatalność dzieci $i$ młodzieży, Warszawa 1977, s. 24; W. Okoń, Stownik pedagogiczny, Warszawa 1992, s. 182.

${ }^{19}$ K. Kuszak, Dynamika rozwoju samodzielności..., s. 59; taż, Dziecko samodzielne w szkole, Poznań 2008, s. 6.

${ }^{20}$ K. Kuszak, Dynamika rozwoju samodzielności..., s. 73. 
Za wskaźniki samodzielności dziecka w wieku przedszkolnym, w odniesieniu do sfery opanowania przez nie osobistych reakcji emocjonalnych i zachowań, można - za autorką - uznać:

- wyrażanie niezadowolenia w formie werbalnej,

- podejmowanie prób zrozumienia i wyjaśnienia zachowań innych,

- podejmowanie prób negocjowania rozwiązania,

- próbę zastapienia reakcji niewerbalnych objawiających się np. niezadowoleniem, zachowaniami będącymi rozwiązaniem problemu ${ }^{21}$.

W sferze kontaktów społecznych - zarówno z osobami bliskimi czy znanymi dziecku, jak i obcymi - znalazły się następujące wyznaczniki zachowań:

- samodzielne wejście do pomieszczenia, w którym przebywali inni,

- przedstawienie się i przekazanie informacji o sobie innym ludziom,

- nawiązanie kontaktu i prowadzenie rozmowy,

- wysuniecie innym osobom propozycji wspólnego działania (zabawy, pracy) ${ }^{22}$.

Jak nadmieniono, artykuł ten ma przybliżyć istotę pracy wychowawczej wśród dzieci w wieku przedszkolnym, jak też wskazać na przykłady tzw. „dobrej praktyki” w odniesieniu do kształtowania samodzielności dziecka w myśleniu i działaniu. Przedmiotem analizy jest placówka przedszkolna pracująca w oparciu o koncepcje pedagogiczną zaproponowaną przez Marię Montessori (1870-1952), podmiotem opracowania - społeczność tejże instytucji: dzieci i osoby dorosłe.

Nauczyciele Przedszkola Miejskiego nr 106 w Łodzi wdrażają do pracy opiekuńczo-wychowawczej i dydaktycznej wskazówki i przesłania M. Montessori od kilkunastu lat. Wśród założeń ich pracy pedagogicznej jest także zgodnie z refleksją M. Montessori, że każda niepotrzebna pomoc jest przeszkoda w rozwoju ${ }^{23}$ - wychowanie dziecka do samodzielności. Warto nadmienić, iż jednym z głównych zadań placówek tworzonych przez Montessori było przygotowanie dziecka do życia - dzieci miały nauczyć się samodzielnie ubierać, myć, nakrywać do stołu, spożywać posiłek, myć naczynia, sprzątać swój pokój. W obecnej rzeczywistości, wspomniana placówka Montessori, wypełnia to właśnie zadanie.

Aspekt usamodzielniania dziecka $\mathrm{w}$ myśleniu i działaniu jest obecny w opracowanym przez wychowawców, pierwszym w Polsce, programie wychowania przedszkolnego pt. „Odkryjmy Montessori raz jeszcze...”. Traktujac pracę z dziećmi jako pasję - podkreślają autorki - dbajac ciagły rozwój zarówno naszych wychowanków, jaki nas samych - wychowawców, stanowimy zespót

${ }^{21}$ Tamże, s. 75.

${ }^{22}$ Tamże, s. 77.

${ }^{23}$ M. Montessori, Aphorismen, „Die Neue Erziehung” 1930, nr 1, s. 17, cytat podaję za: M. Miksza, Zrozumieć Montessori. Czyli Maria Montessori o wychowaniu dziecka, Kraków 2009, s. 20. 
nauczycieli wciaż poszukujacych, doskonalacych swój warsztat zawodowy, otwartych na świat. Pedagogika M. Montessori funkcjonuje w naszym Przedszkolu od 1. września 1996 r. Z perspektywy minionych lat dochodzimy do wniosku, że aby $w$ petni realizować jej zatożenia $i$ odpowiadać na potrzeby dziecka, należy iść z duchem czasu. Szanujac zatożenia M. Montessori, wprowadzając je w codzienne, przedszkolne życie - nie pozostajemy obojętne wobec nowości pojawiajacych się wraz z rozwojem pedagogiki przedszkolnej. Z proponowanych przez wspótczesnq edukacje treści wybieramy te, które stużq doskonaleniu dzieci i nas. Zależy nam również na tym, aby $w$ dobie nieograniczonego dostępu do informacji (,,zmysty dalekie”), umożliwić dziecku poznawanie świata poprzez dziatanie, doświadczanie, odkrywanie i przeżywanie, uruchamiajac jego wtasne - „zmysty bliskie”. (...) Istotnym kierunkiem naszej pracy wychowawczej jest skupienie uwagi na dziecku, jego potrzebach, możliwościach $i$ zainteresowaniach $^{24}$.

Dla klarowności tego artykułu warto przybliżyć, w wąskim zakresie, koncepcję pedagogiki M. Montessori, która wychowanie rozumiała jako wspieranie dziecka od samych narodzin, pomoc dziecku w indywidualnym rozwoju. Istotą wychowania miało być doprowadzenie dziecka do samodzielności, niezależności od dorosłych, odpowiedzialności i miłości do świata ${ }^{25}$. Tak ujęte wychowanie miało mieć charakter pośredni, bowiem równie znacząca, co osoba wychowawcy rolę, pełniło w rozwoju dziecka tzw. „przygotowane otoczenie” w domu, przedszkolu, szkole. Tożsamą, ważną funkcję przypisuje M. Montessori, tak nauczycielowi, jak i otaczającej dziecko rzeczywistości, ukształtowanej przez dorosłego, kiedy w jednej z wypowiedzi na temat podstaw swojej pedagogiki mówi: Przygotowany nauczyciel i przygotowane otoczenie sa praktycznie podstawa naszego wychowania ${ }^{26}$. Ewa Łatacz uznaje te słowa za istotę metody Montessori, którą tworzą właśnie dwa filary: przygotowany nauczyciel i przygotowane wokół dziecka otoczenie ${ }^{27}$. Zarówno nauczyciel, jak i środowisko przedszkolne miały dać dzieciom sposobność nauki stawania się samodzielnym.

Szczególna rola przypada wychowawcy we wzajemnych relacjach z dzieckiem. W świetle poglądów M. Montessori, aby być nauczycielem, nie wystarcza wyłącznie przygotowanie merytoryczno-metodyczne. Pożądanymi cechami nauczyciela, które za Montessori przywołuje Małgorzata Miksza, są: cierpliwość, „mądra rezerwa”, panowanie nad sobą, spokój, skromność oraz odpowiedzialność za rozwój dziecka, wyrastająca z „wewnętrznej postawy moralnej”

${ }^{24}$ R. Czekalska, A. Gaj, B. Lauba, J. Matczak, A. Piecusiak, J. Sosnowska, Odkryjmy Montessori raz jeszcze... Program wychowania przedszkolnego opracowany na podstawie zatożeń pedagogiki Marii Montessori w Przedszkolu Miejskim nr 106 w Łodzi, Kraków 2009, s. 7-8.

${ }^{25}$ M. Miksza, Zrozumieć Montessori..., s. 43.

${ }^{26}$ Cytat podaje za: E. Łatacz, Recepcja teorii pedagogicznej Marii Montessori w Polsce do roku 1939, Łódź 1996, s. 104.

${ }^{27}$ Tamże. 
pedagoga $^{28}$. Nauczyciel-wychowawca powinien umieć odkryć, zrozumieć i przezwyciężyć własne „ograniczenia”, słabości i błędy, które byłyby przeszkodą w relacji z dzieckiem. Największym z btędów, które na nas ciąza - pisała Montessori w 1932 r. - i które przeszkadzaja nam zrozumieć dziecko, jest gniew. (...) Gniew zwiazany jest $z$ wada, która $w$ oczach postronnego obserwatora czesto jawi się jako cnota $i$ właśnie dlatego jest tak niebezpieczna: $z$ dumq ${ }^{29}$. $\mathrm{W}$ innym miejscu podkreślała, iż nauczyciel, jeśli chce dawać wsparcie, musi iść za dzieckiem, swoje własne poczynania, postępowanie uzależnić od dziecka, nie odwrotnie $^{30}$. Taka wskazówka nie oznaczała, że pomoc osób dorosłych jest zbędna, przeciwnie - Montessori sugerowała, iż w procesie dążenia do samodzielności i niezależności, dziecko cały czas doświadcza własnej niezręczności, słabości, niemocy, braku doświadczenia. Prosi wówczas dorosłego o pomoc. Zadaniem nauczyciela jest wesprzeć dziecko, ale rozsądnie, delikatnie, respektując jego prawo do samodzielności, w myśl prośby wypowiedzianej do dorosłego: Pomóz mi samemu to zrobić.

Dla prawidłowego rozwoju dziecko potrzebuje właściwie zorganizowanego środowiska społeczno-kulturowego. Również w tym aspekcie dorośli: nauczyciele, wychowawcy, rodzice mają do wypełnienia określoną rolę, powinni stać się swego rodzaju „łącznikiem” pomiędzy dzieckiem a światem, interpretując go, tłumacząc, objaśniając. Wprowadzanie w świat kultury i cywilizacji następuje za pośrednictwem ,przygotowanego otoczenia”, którego nauczyciel jest nieodłączną częścią. Jak podkreśla M. Miksza, wychowawca pełni tu podwójną rolę: jest ,żywotnym” elementem tegoż otoczenia, a zarazem jego twórcą ${ }^{31}$.

Mając na uwadze postawę nauczyciela, autorka wskazuje na „przykazania”, które M. Montessori sformułowała wobec wychowawcy. Analiza powinności wychowawczych pozwala na konkluzję, iż wiele z nich odnosi się bezpośrednio do działań wspierających proces usamodzielniania dziecka $\mathrm{w}$ środowisku przedszkolnym. Oto one:

1. Nauczyciel ma przede wszystkim zadbać o ład i porzadek wśród przedmiotów, doktadnie sprzqtać otoczenie, troszczyć się o nie tak, aby wygladało czysto i schludnie; ma usuwać skutki używania przedmiotów: załatać, zreperować, odmalować; ma też pamiętać o wychowawczej roli ozdób i dekoracji.

2. Musi nauczyć dzieci korzystania z przedmiotów, dokładnie pokazać, jak przebiega ćwiczenie codziennych praktycznych umiejętności życiowych; ma to zrobić serdecznie $i$ starannie, tak aby dziecko mogło wybrać dowolny przedmiot z otoczenia i umiało zrobić z niego użytek.

\footnotetext{
${ }^{28}$ M. Miksza, Zrozumieć Montessori..., s. 84.

${ }^{29}$ Cytat podaję za: M. Miksza, Zrozumieć Montessori..., s. 83-84.

${ }^{30}$ Tamże, s. 84.

${ }^{31}$ Tamże, s. 85.
} 
3. Nauczyciel ma być aktywny, kiedy wprowadza dziecko $w$ zwiazki z otoczeniem. Ma być pasywny, kiedy relacja ta sie już nawiazała.

4. Musi obserwować dzieci i zważać, by ich sity nie rozpraszaty się nadaremnie, gdy któreś nie może znaleźć potrzebnego przedmiotu albo potrzebuje pomocy.

5. Musi spieszyć tam, doką go dziecko wzywa.

6. Musi stuchać i odpowiedzieć, kiedy dziecko go o to prosi.

7. Musi okazać szacunek dziecku wykonujacemu pracę i nie przerywać mu.

8. Musi okazać szacunek dziecku, które popetnia btędy i nie poprawiać go.

9. Musi okazać szacunek dziecku, które odpoczywa i przyglada się, jak inni pracuja: nie przeszkadzać mu, nie wotać i nie zmuszać do pracy.

10. Musi jednak niestrudzenie próbować dziecku, które popetnia błędy, podsuwać przedmioty, które ono już raz odrzucito. A osiagnie ten cel ożywajac otoczenie swoim milczeniem i swojq troskliwościq: rozważnym milczeniem, tagodnym stowem, obecnościq kogoś, kto kocha.

11. Nauczyciel musi dać odczuć swa obecność dziecku, które szuka, a skryć się przed tym, które znalazło.

12. Nauczyciel ma stanqć przy dziecku, które ukończyło wybranq pracę i twórczo wyczerpało swój zasób energii, i milczqc, podać mu własna dusze jak duchowy przedmiot ${ }^{32}$.

Warto nadmienić, iż znaczącą rolę w procesie wychowania przypisywała Montessori obserwacji pedagogicznej. Właśnie dzięki niej nauczyciel mógł śledzić bieżący rozwój dziecka i dostosowywać działania wychowawczodydaktyczne do jego możliwości, wiedzy, potrzeb oraz zainteresowań.

„Przygotowane otoczenie”, czyli otoczenie wokół dziecka, zorganizowane przez wychowawcę świadomie i celowo, miało dopomagać dzieciom w samorozwoju i samowychowaniu. Można było w nim wyodrębnić następujące elementy:

- materialny:

- budynek przedszkolny i jego otoczenie

- wyposażenie sal: sprzęty, materiał rozwojowy opracowany przez Montessori i inne pomoce dydaktyczne

- osobowy:

- zróżnicowana wiekowo grupa dzieci

- nauczyciele, personel pomocniczy

- rodzice

- strukturalno-dynamiczny ${ }^{33}$ :

- normy, kryteria, struktura przygotowanego otoczenia

- zasady budowy pomocy rozwojowych oraz zasady pracy z nimi

\footnotetext{
${ }^{32}$ Cytat podaję za: M. Miksza, Zrozumieć Montessori..., s. 85-86.

${ }^{33}$ Tamże, s. 64.
} 
- zasada porządku i wolności tkwiąca w przygotowanym otoczeniu, w relacjach pomiędzy dziećmi a otoczeniem i nauczycielem.

Podstawę organizacyjną montessoriańskiego „przygotowanego otoczenia” stanowiły przesłanki filozoficzne (antropologia) oraz empiryczne, które opierały się na długoletnich badaniach eksperymentalnych nad rolą i skutecznością tegoż otoczenia w procesie rozwoju i samokształcenia dziecka ${ }^{34}$.

Mając na uwadze wychowanie dziecka do samodzielności w środowisku przedszkolnym, wskazano przede wszystkim na świadomość, postawę i rolę nauczyciela $\mathrm{z}$ jednej strony oraz otoczenie edukacyjne $-\mathrm{z}$ drugiej. Wspomniane w artykule Przedszkole Miejskie nr 106 w Łodzi, pracujące w oparciu o pedagogikę Marii Montessori, za pośrednictwem nauczycieli i ,przygotowanego otoczenia" realizuje zadania związane $\mathrm{z}$ usamodzielnianiem dzieci w myśleniu i działaniu. Efekty tych działań są istotne. Najważniejsze z nich, jak wynika z rozmów z rodzicami, to umiejętność „odnalezienia się”, „radzenia sobie” w nowym środowisku - na etapie edukacji szkolnej.

Budynek Przedszkola - jako składnik otoczenia w aspekcie materialnym okolony jest dużym ogrodem $\mathrm{z}$ różnorodną roślinnością (drzewa, krzewy, kwiaty), drewnianymi sprzętami do zabaw ruchowych, ścieżkami przyrodniczymi, umożliwiającymi zabawy badawcze oraz $\mathrm{z}$ miejscami wypoczynku (altana, ławki, siedziska). Podczas pobytu w ogrodzie dzieci samodzielnie wybierają miejsce i rodzaj zabawy, łączą się w małe i większe grupy, bądź bawią się indywidualnie. Ogród przedszkolny jest naturalnym „przedłużeniem” jednego z działów pedagogiki Montessori, funkcjonującego w sali przedszkolnej - wychowania dla kultury życia, którego założeniem jest, m.in. zapoznawanie dzieci z przyrodą ożywioną i nieożywioną.

Sale przedszkolne - jasne, przestronne, funkcjonalne - wyposażone są w lekkie, niskie, o prostej konstrukcji meble i sprzęty oraz w pomoce rozwojowe i przedmioty codziennego użytku o wysokich walorach estetycznych. W ,przygotowanym otoczeniu" odgrywają istotną rolę, a ich kształcące znaczenie wynika głównie z faktu dostępności. Dzięki temu, iż dostosowane są rozmiarami do potrzeb dzieci - na miarę ich wzrostu oraz w zasięgu wzroku i rąk - w każdej chwili mogą po nie samodzielnie sięgnaćc $c^{35}$. Manipulując przedmiotami, rozwijają zdolności ruchowe i intelektualne, wzbogacają wiedzę o najbliższym otoczeniu, weryfikują poziom własnej samodzielności. W salach znajdują się niskie zlewozmywaki, w których dzieci myją naczynia po skończonym posiłku, pędzle

${ }^{34}$ E. Łatacz, Recepcja teorii pedagogicznej..., s. 111.

${ }^{35}$ Tak zorganizowane sale przedszkolne odpowiadają wymogom nakreślonym przez M. Montessori. Postulaty Włoszki odnoszące się do wyposażenia placówki były, dla jej współczesnych, nowością, gdyż jak wspomina Zofia Żukiewiczowa, w wielu przedszkolach zmuszano jeszcze wówczas dzieci do wielogodzinnego, nieruchomego siedzenia w amfiteatralnie ustawionych ławkach, pośrodku których stał wykładający nauczyciel. Zob. Z. Żukiewiczowa, Wychowanie przedszkolne, Lwów-Warszawa 1924, s. 114. 
i pojemniki na wodę po działaniach plastycznych, płuczą ściereczki do wycierania stołów, nabierają w pojemniki wodę do zabawy badawczej (np. barwienie i przelewanie wody) czy do konewki przed podlaniem kwiatów.

Istotnym składnikiem „przygotowanego otoczenia” jest specjalnie, empirycznie opracowany przez Montessori zestaw pomocy, tzw. materiał rozwojo$w^{36}$. Odpowiada on w swej konstrukcji i zastosowaniu pojawiającym się w umyśle dziecka wrażliwym cyklom ${ }^{37}$, staje się - według autorki - „kluczem do świata" oraz pośrednikiem w poznawaniu rzeczywistości. Ułatwia samokształcenie poprzez samodzielną realizację podjętych zadań, głównie dlatego, że zawiera tzw. kontrolę błędów. Kontrola błędów (specjalne oznakowanie materiału rozwojowego) pozwala dzieciom na samodzielne sprawowanie, podczas działań z materiałem, owej kontroli i korygowanie ewentualnych błędów (samokontrola). Dzięki temu dziecko ma możliwość czerpania radości z samodzielnie wykonanego zadania, nabiera zaufania we własne siły i pragnie podejmować nowe, trudniejsze ćwiczenia. Zasada samokontroli uniezależnia dzieci od kontroli sprawowanej z zewnątrz przez dorosłych, uczy samodzielności w myśleniu i w dociekaniu prawdy.

Materiał rozwojowy Montessori, będący materialnym wyposażeniem w każdej z pięciu grup przedszkolnych, ułożony jest w kilku działach:

1. ćwiczenia praktycznego życia - można tu odnaleźć stanowisko do tradycyjnego mycia rąk, naczynia do przelewania wody, zestaw do czyszczenia metalu, butów, narzędzia do pielęgnacji ciętych kwiatów, drewniane ramki do zapinania guzików, do przewlekania, wiązania kokardek, tasiemek, koraliki do nawlekania, serwetki, ubrania do składania, małe miotełki, szufelki, ściereczki, trzepaczki do dywanów;

2. ksztatcenie zmystów - dział ten zawiera pomoce wprowadzające $\mathrm{w}$ obszar wymiarów (różowa wieża, brązowe schody, czerwone belki, cylindry do osadzania, kolorowe walce) powierzchni (komoda geometryczna, trójkąty konstrukcyjne) oraz brył geometrycznych; są tu również pomoce kształcące zmysł:

a) wzroku (tabliczki barwne)

b) słuchu (puszki szmerowe, dzwonki),

${ }^{36}$ M. Montessori nie nazwała go pomocami dydaktycznymi, lecz materiałem rozwojowym (według niej pomoc dydaktyczna służy nauczycielowi, nie dziecku), ponieważ dotyczył on nie tylko przekazywania dzieciom wiedzy, ale przede wszystkim stanowił podstawę ich rozwoju. Por. E. Łatacz, Recepcja teorii pedagogicznej..., s. 114.

${ }^{37}$ Wśród charakterystycznych właściwości psychicznych pierwszego etapu rozwoju Montessori wymienia m.in. okresy szczególnej wrażliwości - tzw. „wrażliwe cykle” (wrażliwe fazy). Według niej wrażliwe cykle występują u każdego dziecka, trwają w określonym czasie i momencie, a kiedy napotkają optymalną sytuację, warunki i możliwość przyswajania nowych umiejętności, osiagają największą skuteczność. B. Surma, Pedagogika Montessori - podstawy teoretyczne i twórcze inspiracje w praktyce, Kraków 2008, s. 46 
c) smaku (pojemniki z żywnością o różnym smaku)

d) dotyku (tabliczki szorstko-gładkie),

e) powonienia (pojemniki z zapachami)

f) baryczny (płytki baryczne o różnej ciężkości)

g) termiczny (płytki termiczne o różnej temperaturze);

3. edukacja matematyczna - dział zawiera pomoce, które w sposób konkretny tłumaczą świat matematyki; jest to materiał:

a) w zakresie liczenia od 0 do 10 (czerwono-niebieskie sztangi, wrzeciona do przeliczania, czerwone kółeczka, szorstkie i gładkie cyfry oraz kolorowe perły)

b) wprowadzające w system dziesiętny (,złote perły”, karty liczbowe)

c) do liczenia w zakresie $11-19,19-99$ oraz powyżej 100;

4. ksztatcenie językowe - można tu odnaleźć pomoce, rozwijające mowę dziecka, wprowadzające w świat czytania i pisania:

a) kształcące u dzieci:

- umiejętność czytania (przedmioty i obrazki z podpisami, książki)

- umiejętność pisania (metalowe ramki, litery z papieru szorstkiego, ruchomy alfabet)

b) wprowadzające trudności językowe (dwuznaki, zmiękczenia)

c) do nauki gramatyki;

5. wychowanie dla kultury życia - dział zawiera pomoce z zakresu przyrody, biologii, geografii, astronomii (np. globusy, mapy części świata, kontynentów, komoda biologiczna, flagi państwowe);

6. wychowanie religijne - na jego wyposażenie składają się: Pismo Święte, krzyż, świece, książeczki z przypowieściami, obrazki o tematyce religijnej, figurki świętych, różaniec.

W salach znajdują się również inne pomoce dydaktyczne (układanki, puzzle, gry, zabawki) spełniające zasady pracy z materiałem rozwojowym.

Wśród wymienionych, pomocami, które w sposób niejako naturalny przygotowują dziecko do życia, zachęcają do zdobywania coraz większej samodzielności są pomoce do praktycznych ćwiczeń codziennych. Ćwiczenia te odpowiadają naturalnemu pędowi dziecka do ruchu, aktywnego działania, wspomagają koordynację ruchową, pozwalają na naukę konkretnych umiejętności potrzebnych w codziennym życiu. Sam element powtarzania danej czynności, np. zapinanie guzików, wiązanie sznurówek, nalewanie wody do naczynia czy wycieranie ściereczką stolika - jest w tym przypadku najistotniejszy ${ }^{38}$. Poprzez

${ }^{38}$ Dzieci w wieku przedszkolnym interesują się zajęciami domowymi, chętnie naśladują gotowanie, sprzątanie, nakrywanie do stołu. Z upodobaniem czynności te powtarzają wielokrotnie. Dorosły sprząta, aby osiągnąć cel, dla małego dziecka sprzątanie czy „gotowanie” jest zabawą. Powtarzającemu daną czynność dziecku początkowo nie zależy na konkretnym celu, radość i satysfakcję daje mu sama możliwość jej wykonania. Wielokrotnie może wycierać ściereczką ten sam stolik, zamiatać podłogę czy czyścić pastą dawno już „wypolerowany” but. Po jakimś czasie 
systematyczne powtarzanie danej czynności dziecko nabywa wprawy, dochodząc niejednokrotnie do perfekcji i samodzielności w danym zakresie. Swoboda poruszania się po sali, samodzielne korzystanie ze zgromadzonego materiału rozwojowego oraz specjalnie dobierane ćwiczenia umożliwiają mu życie codziennym, powtarzającym się rytmem. M. Montessori podkreślała: Jeśli dokładanie się nad tym zastanowimy, ćwiczenia praktycznego życia sq prawidtowa gimnastyka, a tym, co szkolac czyni wszystkie ruchy subtelnymi, jest samo otoczenie. To jest coś innego niż prace ręczne, w wyniku których powstaje coś nowego (...). Zwinać dywan, wypastować buty, wyczyścić miskę albo podtoge, nakryć stót, otwierać i zamykać szuflady, klapy, drzwi, okna, posprzqtać pokój, ustawić porzadnie krzesto, zaciagnać zastone, przestawić mebel, itp. - to sa ćwiczenia, przy których wkrótce całe ciało coś czyni, wkrótce ten czy inny ruch staje się wyćwiczonym i doprowadzonym do perfekcji ${ }^{39}$.

Aspekt osobowy przygotowanego otoczenia w placówce montessoriańskiej tworzą dzieci zróżnicowane wiekowo, rodzice, nauczyciele oraz personel pomocniczy. Warto nadmienić, iż M. Montessori zachęcała, aby w grupach przedszkolnych przebywały ze sobą dzieci z co najmniej trzech roczników w Przedszkolu Miejskim nr 106 funkcjonują grupy, w których na wzór grupy rodzinnej, wspólnie bawią się, uczą i pracują dzieci 3-, 4-, 5- i 6-letnie. Różnorodność wiekowa, ale także rozwojowa jest tu podstawą samowychowania, pozwala na nabywanie postaw prospołecznych: wzajemnej pomocy, życzliwości i współpracy, umożliwia obustronną naukę.

Praca wychowawczo-dydaktyczna z dziećmi, we wspomnianym Przedszkolu Montessori odbywa się z zastosowaniem różnych form dziecięcej aktywności. Jest to:

- aktywność indywidualna: zabawa, nauka, praca (zakłada także kontakt z nauczycielem - tzw. „lekcje słowne”),

- aktywność zespołowa w małych grupach (może przebiegać również z nauczycielem)

- aktywność zespołowa z całą grupą (są to najczęściej zajęcia proponowane przez nauczyciela, np. ruchowe, plastyczne, muzyczne, integracyjne, tzw. „lekcje ciszy”).

We wspomaganiu rozwoju dziecka ważną rolę, obok nauczycieli, pełnią pozostali pracownicy Przedszkola. Jednolitość oddziaływań, wspólny kierunek myślenia i konsekwencja $\mathrm{w}$ wychowywaniu do samodzielności są podstawą w nabywaniu przez dzieci wielu umiejętności. Zatem, w jaki sposób w środowisku przedszkolnym, dorośli - główna jednak rola przypada tu nauczycielom starają się wspierać dążenia dzieci do usamodzielnienia? Oprócz kreowania

dziecko zauważa celowość swej pracy i stara się osiagnąć także cel zewnętrzny, a więc po prostu wykonać dane zadanie.

${ }^{39}$ Cytat podaję za: E. Łatacz, Recepcja teorii pedagogicznej..., s. 124. 
i przystosowywania otoczenia, by stanowiło zachętę do działan - zabawy, nauki, pracy - nauczyciele w Przedszkolu Miejskim nr 106 w Łodzi:

- Tworzą wokół dziecka atmosferę bezpieczeństwa i akceptacji, wolności i swobody, okazując cierpliwość dla dziecięcych zmagań. Każdemu dziecku dany jest czas na doskonalenie umiejętności wykonania danej czynności, nie zawsze bowiem efekt działania musi być natychmiast zadawalający. Jak nadmieniono, zdarza się, że dziecko bardziej pochłonięte jest samym faktem wykonywania danej czynności, niż precyzyjnością jej wypełnienia. Poprzez ciągłe powtarzanie nabywa wprawy, dochodząc niejednokrotnie do perfekcji i samodzielności w danym zakresie.

- „Podążają za dzieckiem”, stawiając wymagania na miarę jego wieku i możliwości.

- Zachęcają do nabywania i ćwiczenia nowych umiejętności przydatnych w życiu codziennym (np. przygotowanie śniadania, nalewanie napojów, zupy, nakładanie surówek, wytarcie stołu, odniesienie naczyń po skończonym posiłku, mycie naczyń, rozłożenie materiałów do zajęć, porządkowanie miejsc pracy po zabawie, zajęciach, zamiatanie, ubieranie się i rozbieranie, karmienie zwierząt: rybek, żółwia, chomika, pielęgnacja kwiatów). Dzieci chcą uczestniczyć „w życiu dorosłych”. Jeśli nauczyciel nie pozwala na to uczestnictwo, wówczas dziecko w zabawie kompensuje to, czego brak mu w rzeczywistości, naśladując zajęcia dorosłych „na niby”. Nauczyciele tworzą, więc otoczenie sprzyjające autentycznej pracy, gromadząc przedmioty codziennego użytku w rozmiarach odpowiednich dla małego dziecka.

- Okazują szacunek dla zmagań dziecka z przedszkolną rzeczywistością, dając mu przy tym prawo do nauki poprzez próby i błędy, prawo do eksperymentowania i doświadczania.

- Starają się nie chronić nadmiernie przed doświadczaniem niepowodzenia, pamiętając o słowach niemieckiego pedagoga - Hansa Elsnera, który mówił: Szczebel po szczeblu dziecko w swym rozwoju kroczy własnq drogq. Swe kroki wyznacza ono samo. Usuwajmy kamienie spod jego nóg tylko wtedy, gdy jest to konieczne $e^{40}$.

- Zachęcaja, w sytuacji niepowodzenia, do ponawiania prób. Podejście takie uczy dziecko dążenia do realizacji zamierzonych celów, doprowadzania zadań do końca.

- Nie okazują dziecku zniecierpliwienia, jeśli podczas zabawy czy pracy „coś” upadnie, przewróci się, stłucze lub rozleje. Najczęściej używanym jest wówczas komunikat: „Nic się nie stało” albo: „Każdemu może się to przydarzyć”.

- Nie uzależniają dziecka od siebie, nie narzucają sposobu wykonania zadania, uważnie obserwują dziecięce działania, by w razie pojawienia się „krytyczne-

\footnotetext{
${ }^{40}$ Hans Elsner - nauczyciel ze szkoły Montessori w Niemczech, w Kolonii. Cytat podaję za: M. Miksza, Zrozumieć Montessori..., s. 76.
} 
go momentu", bądź na prośbę dziecka, przyjść z pomocą i wesprzeć samodzielne wysiłki. Wprawdzie udzielają pochwał i innych społecznych wzmocnień, jednak ostrożnie formułują oceny odnoszące się do pracy dzieci. Dążą do tego, aby rozwijały $\mathrm{w}$ sobie poczucie satysfakcji $\mathrm{z}$ samego działania, nie uzależniały się od aprobaty czy opinii innych. Pomagają dzieciom w dokonywaniu samooceny posiadanej wiedzy i umiejętności, co stanowi podstawę kształtowania się pozytywnego obrazu ich własnej osoby.

- Nie wyręczają dziecka, ale cierpliwie pomagają w zdobywaniu umiejętności, wskazując kolejne etapy wykonania danej czynności, stosując zasadę stopniowania trudności. Powoli wycofują swą pomoc, umożliwiając samodzielne działanie. Przyjmując taką postawę nauczyciel ułatwia dziecku osiąnięcie sukcesu, ale przede wszystkim wzbudza pozytywną motywację.

- Respektują zasadę wolności w wychowaniu (a nie od wychowania), która jest wolnością ,zorganizowaną”, o określonych granicach ${ }^{41}$. Warunkiem bezpiecznego prowadzenia dzieci ku samodzielności jest stworzenie im przestrzeni w sensie fizycznym i duchowym, w której będą mogły aktywnie działać i realizować zadania. Dziecko otrzymuje tyle wolności ${ }^{42}$ i swobody ${ }^{43}$, ile jest w stanie przyjąć. Wolność pozwala mu na ukształtowanie postawy odpowiedzialności osobistej i społecznej. Zasada wolności nie oznacza swobody absolutnej, kojarzonej ze swawolą, ale samodyscyplinę opartą na świadomie respektowanych regułach życiowych i normach społecznych.

Jak nadmieniono, samodzielność dziecka w pedagogice Montessori to nie tylko wymiar radzenia sobie z codziennymi „obowiązkami”, ale także wolność, pozwalająca na dokonywanie wyboru. Pojawia się zatem pytanie: Co dziecko może samodzielnie wybrać w warunkach przedszkola?, O czym może zadecydować samodzielnie? W Przedszkolu Miejskim nr 106 w Łodzi, w przygotowanym otoczeniu dzieci mają możliwość wyboru:

- miejsca aktywności: pracy, zabawy, nauki (przy stoliku, na dywanie, na podłodze, w różnych fragmentach sali),

- przedmiotu aktywności (różnorodny materiał rozwojowy, inne pomoce dydaktyczne, zabawki oraz sprzęty znajdujące się w sali),

${ }^{41}$ Tak rozumianą wolność, nauczycielki szkoły Montessori w Szwecji, porównują do koryta rzeki prowadzącego do morza; woda może w nim płynąć swobodnie, ale w jego granicach. Zob. K. S. Wennerström, M. B. Smeds, Pedagogika Montessori w przedszkolu i szkole, Kraków 2009, s. 47.

${ }^{42}$ „Wolność stanowi o ludzkiej egzystencji człowieka, poprzez nią i dzięki niej kreuje on rzeczywistość i przyszłość, tworzy swój świat i siebie samego”. Por. A. M. de Tchorzewski (red.), Wolność jako wartość i problem edukacyjny, Bydgoszcz 1999, s. 7.

${ }^{43}$ Swoboda jest jednym z synonimów wolności, może oznaczać nieskrępowanie, indywidualizację, dobrowolność. Inne synonimy pojęcia „wolność” to: wyzwolenie, niezależność, demokracja. Tamże. 
- czasu i tempa aktywności: zabawy, nauki, pracy (pewne ograniczenia w tym zakresie powodują posiłki, odbywające się w stałych, oznaczonych godzinach oraz zajęcia dodatkowe, np. język angielski, zajęcia taneczne, logopedyczne)

- rówieśników (aktywność indywidualna, zespołowa, grupowa).

Oprócz tego dzieci mają możliwość podejmowania decyzji, odnośnie:

- ilości i różnorodności spożywanego posiłku,

- sposobu rozwiązania sytuacji trudnej, konfliktowej, pod warunkiem, że wybór strategii jest zgodny z ustalonymi wcześniej zasadami współżycia w grupie (dzięki podejmowanym decyzjom dzieci nabywają umiejętności w samodzielnym rozwiązywaniu problemów),

- przyjmowania obowiązków (dyżurów) oraz ról społecznych podczas zabawy, nauki i pracy.

Samodzielne dokonywanie wyborów daje dzieciom wolność, swobodę, ale też pozwala na obserwowanie skutków oraz doświadczanie konsekwencji osobistych wyborów. Uczy ponadto odpowiedzialności za własne działania i decyzje. $Z$ samodzielnego dziecka, jak nadmieniono, wyrasta samodzielny dorosły, radzący sobie z wymaganiami stawianymi przez życie.

- Wspólnie z dziećmi ustalają reguły współżycia w grupie. Wymiar wspólnotowego określenia reguł i norm grupowych powoduje, z jednej strony dobrowolne podporządkowanie się ich ustaleniom, $\mathrm{z}$ drugiej natomiast - pozwala na osiaganie samodzielności w zakresie kontrolowania własnego zachowania w obrębie tychże norm. Swoboda i samodzielność w środowisku przedszkolnym wymaga wyznaczenia granic, ustalenia ram postępowania i wzorów zachowań społecznych. Nauczyciele uświadamiają dzieciom, że ich wolność ma granice, kończy się tam, gdzie zaczyna się swoboda innego dziecka oraz, że przywileje, które dotyczą jednego dziecka, odnoszą się również do innych.

Pomoc dzieciom w dążeniu do samodzielności zakłada porozumienie i dia$\log \mathrm{z}$ ich rodzicami, opiekunami. Współpraca z rodziną ma na celu uzgodnienie wspólnego kierunku pracy z dzieckiem, wspierania go we wszystkich obszarach rozwojowych. Jak pokazują jednak badania ankietowe przeprowadzone wśród rodziców dzieci, w Przedszkolu Miejskim nr 106 w Łodzi, rodzice czasami nie pozwalają dzieciom na samodzielność, a im młodsze dziecko, tym obawy wynikające z podejmowania przez nie własnych inicjatyw są większe. Wyniki badań wskazują, iż według rodziców, oprócz takich czynników jak: „brak czasu”, „pośpiech”, czy „powolne lub niewłaściwe wykonanie czynności”, to głównie strach o bezpieczeństwo dziecka determinuje decyzję rodzica o ograniczeniu samodzielności. Oto niektóre z odpowiedzi na pytanie: „Co powoduje, że (czasami, zawsze) obawia się Pani (Pan) pozwolić dziecku na samodzielne działanie?", uzyskane od rodziców dzieci 6-letnich: 
- Niepokój o efekt tego działania.

- Obawa, że podjęta przez dziecko decyzja będzie zagrażała jego życiu lub zdrowiu, badź przyczyni się do zniszczenia lub naruszenia czyjegoś mienia.

- Obawa o bezpieczeństwo, w przypadku zwiedzania nowych miejsc lub używania sprzętu mechanicznego.

- Obawa, że podczas naszej nieuwagi dziecko nierozważnie poszerzy zakres tego działania (kuchenka gazowa - samodzielnie zaparzona herbata; komputer niebezpieczne strony, itp.

- Gdy dziecko będzie samodzielnie robić kanapkę, to może skaleczyć się.

- Nie zawsze potrafi wyobrazić sobie konsekwencje swojego działania.

Wśród odpowiedzi na pytanie, Co Pani (Pan) robi za dziecko, chociaż wie, $\dot{z} e$ nie powinna (powinien)?, przeważają czynności związane $\mathrm{z}$ obszarem samoobsługi, takie jak: ubieranie, składanie ubrań, wiązanie butów, nalewanie napojów, dokarmianie, ale pojawia się też sprzątanie pokoju dziecka lub (i) zabawek. Analogiczne czynności i sytuacje wykorzystywane są przez rodziców w domu, w celu usamodzielniania dziecka. Są to m.in.: czynności związane $\mathrm{z}$ codzienną toaletą, utrzymywanie porządku $\mathrm{w}$ pokoju, pomoc $\mathrm{w}$ drobnych pracach domowych, ale również gry, zabawy, czytanie książek, rozmowa z dzieckiem i zachęcanie do podejmowania własnych decyzji.

Rodziców dzieci 6-letnich zapytano w ankiecie o rodzaj umiejętności w zakresie samodzielności: w obszarze samoobsługi, w myśleniu oraz w realizacji zadań (działaniu), nabytych przez dziecko w środowisku przedszkolnym. Według opinii rodziców, na płaszczyźnie samoobsługi dzieci potrafią m.in.: samodzielnie wykonać czynności toaletowe, związane z pielęgnacją własnego ciała (mycie, czesanie) oraz ubieraniem się (wkładanie odzieży, zapinanie guzików, ekspresów, zakładanie butów, wiązanie sznurówek), samodzielnie przygotować proste posiłki, spożywać posiłki, sprzątać i zmywać naczynia po posiłkach. Do tej kategorii rodzice zakwalifikowali również działania, jak: samodzielne porządkowanie miejsca zabawy, sprzątanie własnego pokoju i pomoc $\mathrm{w}$ pracach domowych, które to czynności związane są raczej z samodzielnością dzieci w obszarze realizacji zadań.

Odpowiedzi badanych, w kategorii umiejętności dziecka w samodzielnym myśleniu, nabytych w środowisku przedszkolnym, wskazują na:

- Kreatywność dziecka w zabawie, wymyślanie tematyki prac plastycznych.

- Wyrażanie ciekawych i zaskakujacych pogladów i spostrzeżeń, duża logika w myśleniu, duża spostrzegawczość.

- Samodzielne wychodzenie z inicjatywa, np. spędzania wolnego czasu.

- Posiadanie wtasnej opinii. Dziecko nie boi się pytać i wyrażać swoje zdanie.

- Podejmowanie prób w rozwiazywaniu problemów.

- Podejmowanie niektórych decyzji, wyrażenie wtasnej opinii na niektóre tematy i uzasadnienie jej, umiejętność przekonania do wtasnego zdania.

- Samodzielna ocena sytuacji, stuchanie, twórcze prace. 
Wśród tych odpowiedzi pojawiła się opinia, z której wynika, iż pomimo, pewnych osiagnięć: Dziecko ma nadal problem $w$ samodzielnym myśleniu, ale to już nie jest tak nasilone, jak chociażby trzy lata temu. Da się zaobserwować ogromny wptyw, jak maja na dziecko rówieśnicy.

W zakresie samodzielności dziecka, zdobytej w Przedszkolu w obszarze realizacji zadań, respondenci wskazują na działania związane głównie z zabawą i nauką, ale pojawiają się też opinie, świadczące o umiejętności pokonywania trudności podczas wykonywania zadań:

- Dziecko potrafi samodzielnie zorganizować sobie zabawe lub pracę. Często samodzielnie rysuje, sam wybiera artykuty $w$ sklepie. Lubi wykonywać prace doktadnie i powoli, ma zawsze dużo czasu.

- Dziecko samodzielnie rysuje, pisze, liczy, czyta, samodzielnie organizuje zabawe.

- Samodzielnie wykonuje zadania w ksiażeczkach, karmi zwierzęta (pamięta o tym!)

- Syn samodzielnie spędza czas i organizuje zabawy dla rówieśników.

- Podejmuje udane próby w nawiqzywaniu kontaktów z rówieśnikami.

- Dziecko samo sobie znajduje zajęcia, chętnie uczestniczy w nowych czynnościach, chce poznawania nowych rzeczy.

- Dziecko samo układa klocki, wymyśla zabawy, gdy przychodza koledzy.

- Nauczyto się i uczy się nadal, jak radzić sobie z trudnościami.

Jedna wypowiedź świadczy o dylemacie rodziców, związanym z kwestią usamodzielniania dziecka podczas realizacji zadań: Syn wciaż zadaje pytanie: co mam robić? Brak mu pomystów na zajęcie, zabawę. Wymuszamy na dziecku samodzielność, świadomi, że jest to proces dtugotrwaty.

Zebrany materiał badawczy pomaga nauczycielom w refleksji nad świadomością i odpowiedzialnością dorosłych - rodziców w kreowaniu otoczenia „domowego", wspierającego samodzielne działania i stanowi płaszczyznę do dyskusji. Namysł nad możliwością „wykorzystania” przez dorosłych codziennych sytuacji w przedszkolu i w domu w usamodzielnianiu dziecka, jest podstawą osiaggania przez niego tej kompetencji. Wspólne dążenie rodziców, nauczycieli oraz całego personelu przedszkola zdecydowanie ułatwia i przyśpiesza proces kształtowania się niezależności dziecka od dorosłych. Dziecko, które w przedszkolu czy w domu może swobodnie rozwijać swą samodzielność, w przyszłości będzie zaradne, pewne siebie, odpowiedzialne i odważne w podejmowaniu decyzji. I przeciwnie - obawa, ograniczanie i wyręczanie w wielu czynnościach, może powodować przeżywanie przez dzieci uczuć negatywnych, takich jak: gniew, zniechęcenie, bezradność, lęk ${ }^{44}$.

${ }^{44}$ K. Szczepkowska-Szczęśniak, K. Uniszewska, Droga do samodzielności, [w:] Doradca Nauczyciela Sześciolatków, Materiały metodyczne dla nauczycieli opracowane w wyniku projektu Badanie gotowości szkolnej sześciolatków, Centrum Metodyczne Pomocy Psychologiczno-Pedagogicznej, Warszawa 2006, s. 4-33. 
Wychowanie do samodzielności jest procesem, jest drogą rozwoju indywidualnego, której przejście prowadzi - najpierw w wymiarze dziecięcym, potem dorosłym - do zwiększenia kontroli nad własnym życiem. Pierwsze przeżycia dziecka w tym zakresie - w domu, w przedszkolu, w szkole - stają się doświadczeniami bazowymi, punktem odniesienia dla dalszej edukacji. Ogromna rola spoczywa więc na wychowawcach i rodzicach. Dzięki ich świadomości i odpowiedzialnej postawie dziecko jest w stanie samodzielnie radzić sobie z wymaganiami stawianymi przez życie, najpierw w kontekście obowiązków szkolnych, a następnie rodzinnych i społecznych.

JOANNA SOSNOWSKA

\section{Educating for self-reliance - the role of a kindergarten teacher in creating environment for children}

Self-reliance in behavioral concepts is an ability allowing an individual to proceed an activity regardless of the environment. It is the ability acquired by means of systematical practice. It is a lifelong process. However, the most intense changes occur in childhood and adolescence. A selfreliant child means a self-reliant adult in the future.

Educating a child for self-reliance is a responsibility of adults, i.e. teachers and parents. There are no ready made patterns of forming a small child's self-reliance which is determined by many factors. Every child has their own pace of development and the level of self-reliance depends on their capacity, abilities and the environment they are in. There are numerous school and kindergarten situations which a teacher can use to teach and improve children's self-reliance. One of them is organizing educational environment in such a way that no-one should help out children in their everyday activities such as personal hygiene, meals, playing, tidying their classrooms, being on duty as well as interpersonal communication. 